\title{
Resin Tapping History of an Aleppo Pine Forest in Central Greece
}

\author{
A.M. Papadopoulos*
}

TEI Stereas Elladas, Department of Forestry and Natural Environment Management, 36100 Karpenissi, Greece

\begin{abstract}
The resin tapping history of an Aleppo pine (Pinus halepensis ssp halepensis) forest in Northern Evia, Central Greece was investigated by standard dendrochronological methods. Cross-sections disks of tapped and non-tapped trees were taken from a representative, concerning structure and management, Aleppo pine stand. The identification of resin tapping scars in the cross-sections, combined with tree-rings dating, provided information about tapping methods applied, number and width of tapping faces, tree diameter on the time of tapping commencement and tapping duration. The measurement of tree ring width and the proportion of latewood of tapped and non-tapped trees showed a reduction in the average tree-ring width by $14.1 \%$ and in the proportion of latewood by $6 \%$ caused by tapping. Tree-ring examination showed that tapping causes severe anomalies in wood like deformations, callous tissues and discoloration. The above information is a helpful tool for the management and study of the Greek resin tapping methods of Aleppo pine forests.
\end{abstract}

Keywords: Dendrochronology, growth, latewood, Pinus halepensis ssp halepensis, resin tapping scars, tree-rings.

\section{INTRODUCTION}

Resin tapping is a traditional activity in Greece practiced since antiquity in Aleppo pine forests. There were two major tapping methods applied in Greece, the "Chipping" and the "Debarking and use of sulfuric acid" [1]. The first is the older one and no longer in use. In this method, a wound was created mechanically by an ax causing incision fronts of 1.5 $\mathrm{cm}$ depth into the wood. In Greece there were 3 different versions of this method based on the tool used and the time lapse between applications. In the second method, which is a newer one, the external part of the wood is peeled and then a paste of chemical irritant (sulfuric acid paste, etc.) is applied onto the wound. Stands, mainly of old and middle aged trees, bear characteristic tapping marks in their trunks from scars of previous tapping faces (Fig. 1).

Tapping scars, either visible on the trunk or enclosed inside the wood after radial growth, can be studied to provide information on the history and the techniques applied. This study can be done by the use of dendrochrono$\operatorname{logy}$ in a similar way as for fire scars, rock-fall scars or it scars caused by any other factor [2].

The purpose of the present work is to investigate the past resin tapping procedures and their impact on tree radial growth and wood anatomical features. The Greek resin tapping tradition is worthy of a multifaceted study since, due to its long history, it can provide useful information for the management of tapped forests [3].

\section{METHODS}

A total of 15 cross sections (disks of approximately 7-10 $\mathrm{cm}$ thickness) were taken from stumps of a previously

*Address correspondence to this author at the TEI Stereas Elladas, Department of Forestry and Natural Environment Management, 36100 Karpenissi, Greece; Tel: 00302237025063; Fax: 00302237024035 ;

E-mail: ampapadopoulos@teilam.gr

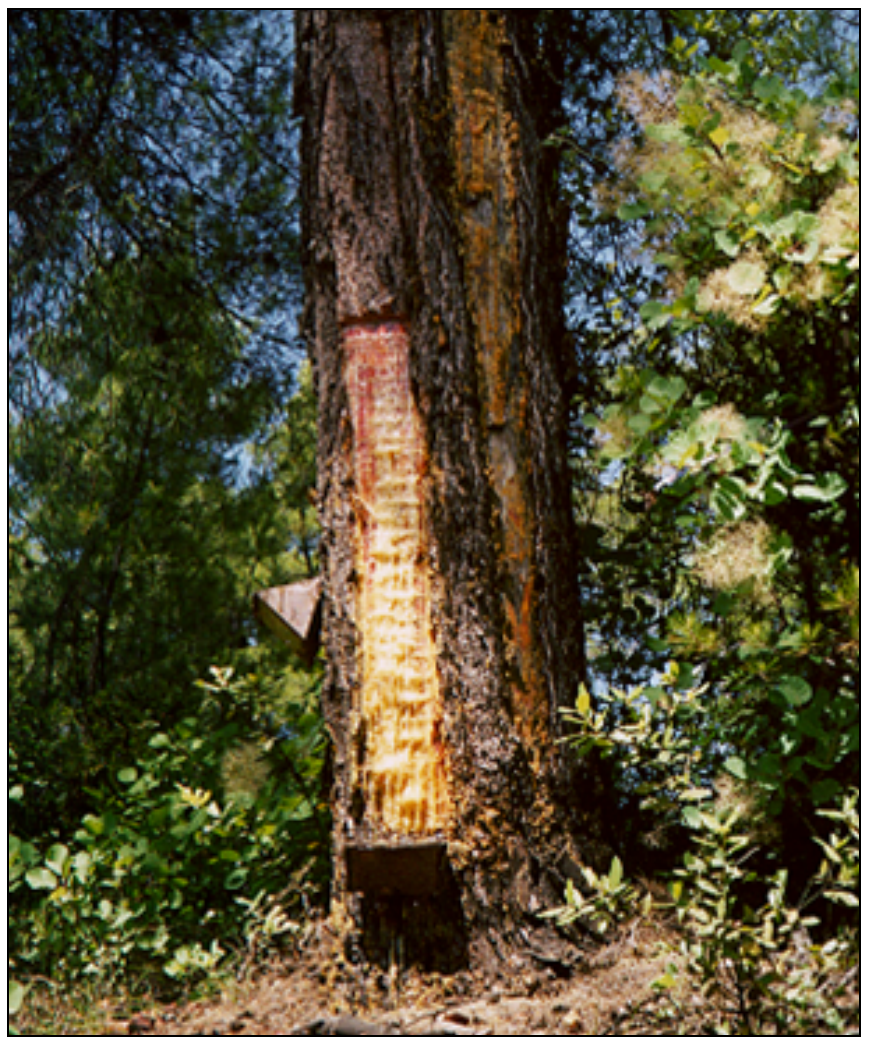

Fig. (1). Tapping faces (the resin flow area).

harvested Aleppo pine stand on the island of Evia, Central Greece ( $38^{\circ} 54^{\prime} 26^{\prime \prime}, 23^{\circ} 10^{\prime} 15^{\prime \prime}, 219 \mathrm{~m}$ a.s.1.). Of the disks, 10 derived from tapped and 5 from non-tapped trees. The stand can be characterized as a typical one for tapped forests as to its structure and to its previous management regime applied. Stumps of tapped trees were randomly selected among the largest ones remained after a regeneration harvest made in the time period 1999-2008, bearing intense tapping 
signs. There were only a few non-tapped trees stumps and were indicated by the local resin collectors.

The samples were processed and cross dated using standard dendrochronological techniques $[4,5]$. To assist the cross-dating work, three mean chronologies of non-tapped Aleppo pine forests, close to the sampling area, were used [6]. Tree-ring widths to the nearest of $0.01 \mathrm{~mm}$ and the proportion of latewood (\%) were measured in three radial directions, using the Windendro system [7]. A total of thirty and fifteen elementary chronologies were constructed from tree ring width and late wood proportion measurements, for tapped and non-tapped trees respectively. Subsequently, and based on the above measurements, four mean chronologies (tree ring width of tapped and non-tapped trees and latewood proportion of tapped and non-tapped trees), were constructed and used for analyses and comparisons.

Tapping scars were detected and dated at the crosssections of the trees. Initially the tapping method applied to each cross-section was identified ("Chipping" or "Debarking and use of sulfuric acid" [1]) and subsequently the tapping face width was measured. In the cases where the chipping method was used, the tapping face was straight with rings missing from the central portion of the tapping face due to wood removal along with the bark. On the contrary, in the case of debarking, the tapping face form was curved and the last ring was displayed in the entire width of the scar. Finally, specific wood anatomical features caused by treetapping such as discoloration and callous-tissue formation, were identified.

\section{RESULTS}

Fig. (2) presents the results from the tapping history investigation of the forest under study. Tapping commenced in 1951 and continued until the period 1997-2008 when all regeneration harvests of the stand were completed. Tapping was conducted from 1 to 6 side faces (more frequently 4 side faces) in each tree, performed up to 1971 by the chipping method and, after this year, by the sulfuric acid debarking method. The scars were sequential and, in many cases, opposite to each other on their position to the disk (diametrically). Faces width ranged from 3.9 to $16.3 \mathrm{~cm}$ (mean $12 \mathrm{~cm}$ ). An individual side face was used from 3 to 13 years (mean 7 years). Minimum tree breast-height diameter for the commencement of tapping was 21 to $36 \mathrm{~cm}$ (mean 26 $\mathrm{cm})$. A tree was used for tapping for a total period of 16 to 37 years (mean 25 years). Tapped trees were harvested at the age of 75 to 110 years (mean age 83 years). Tapping, as shown by frequency of face opening, is most pronounced in the time period 1951-1977.

Tapped trees compared to non-tapped and for the tapping time period 1951-1997, show a decrease in mean tree ring width by $14.1 \%$ (average tree ring width of non-tapped trees $2.41 \pm 0.85 \mathrm{~mm}$ and $2.07 \pm 0.7 \mathrm{~mm}$ for tapped), and in late wood proportion by $6 \%$ respectively (Fig. 3 ).

Tapping, irrespectively of the method applied, caused intensive wounds in the tree trunk leading to wood deformation and callous tissue formation. It also caused intense wood discoloration towards tapping faces possibly due to moisture loss and wood torching [1]. This discoloration may have a wedge shape form towards the direction of the faces, possibly due to intensive tapping [1] and due to the use of stimulating substances used for increasing resin outflow [8]. When tapping is applied in 3 or 4 diametrically opposite faces, such discolorations form a radial design or a cross (Fig. 4). The appearance of crosses in trees, besides tapping, may occur for other reasons as well (encased branches) and to which some local people falsely attribute a specific symbolism [9].

\section{CONCLUSIONS AND DISCUSSION}

Resin tapping was the main activity of the investigated forest for the, approximately, past 50 years. Tapping, as

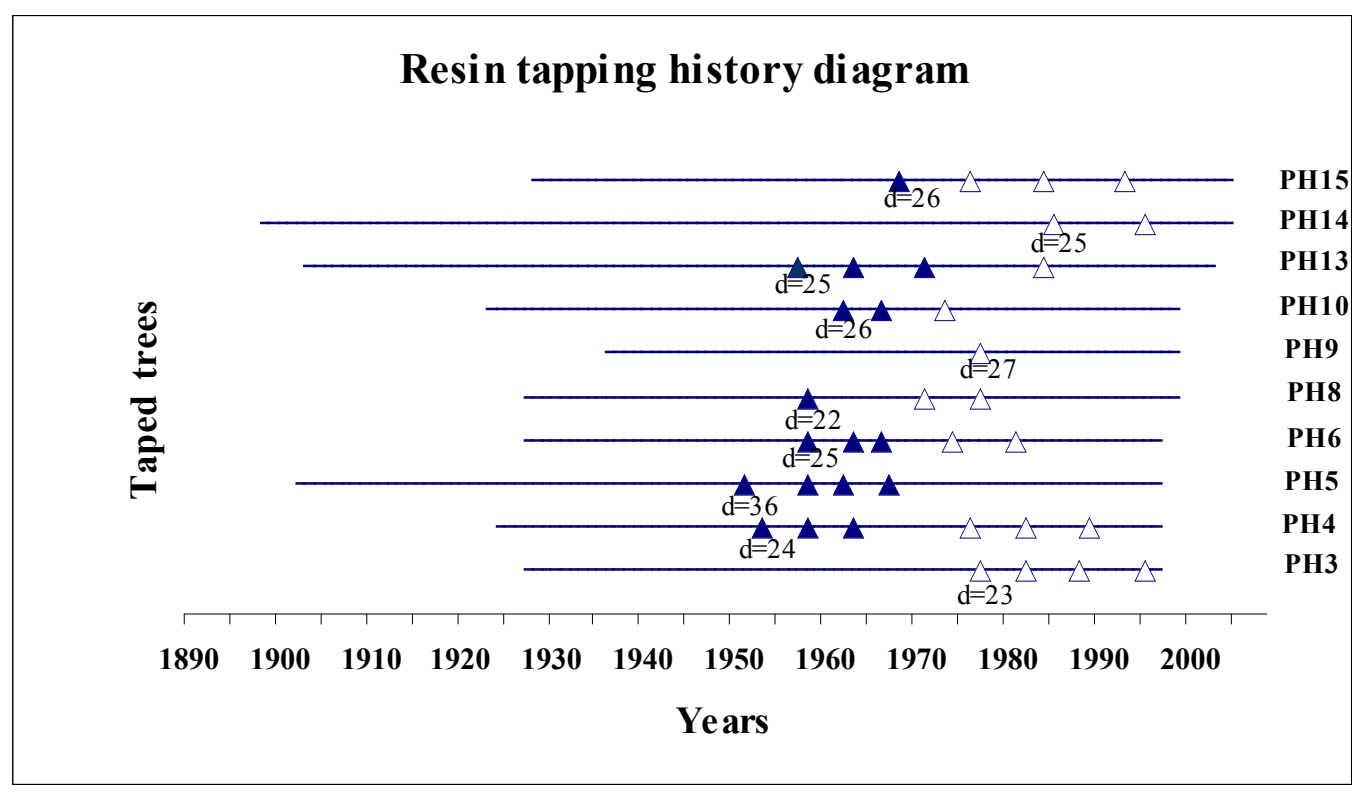

Fig. (2). Chronology of tapped trees (line). Triangles indicate the commencement year of side face opening (by dark triangles the chipping method, by fair the debarking one). Tree diameter on initial tapping is indicated under the first triangle. 


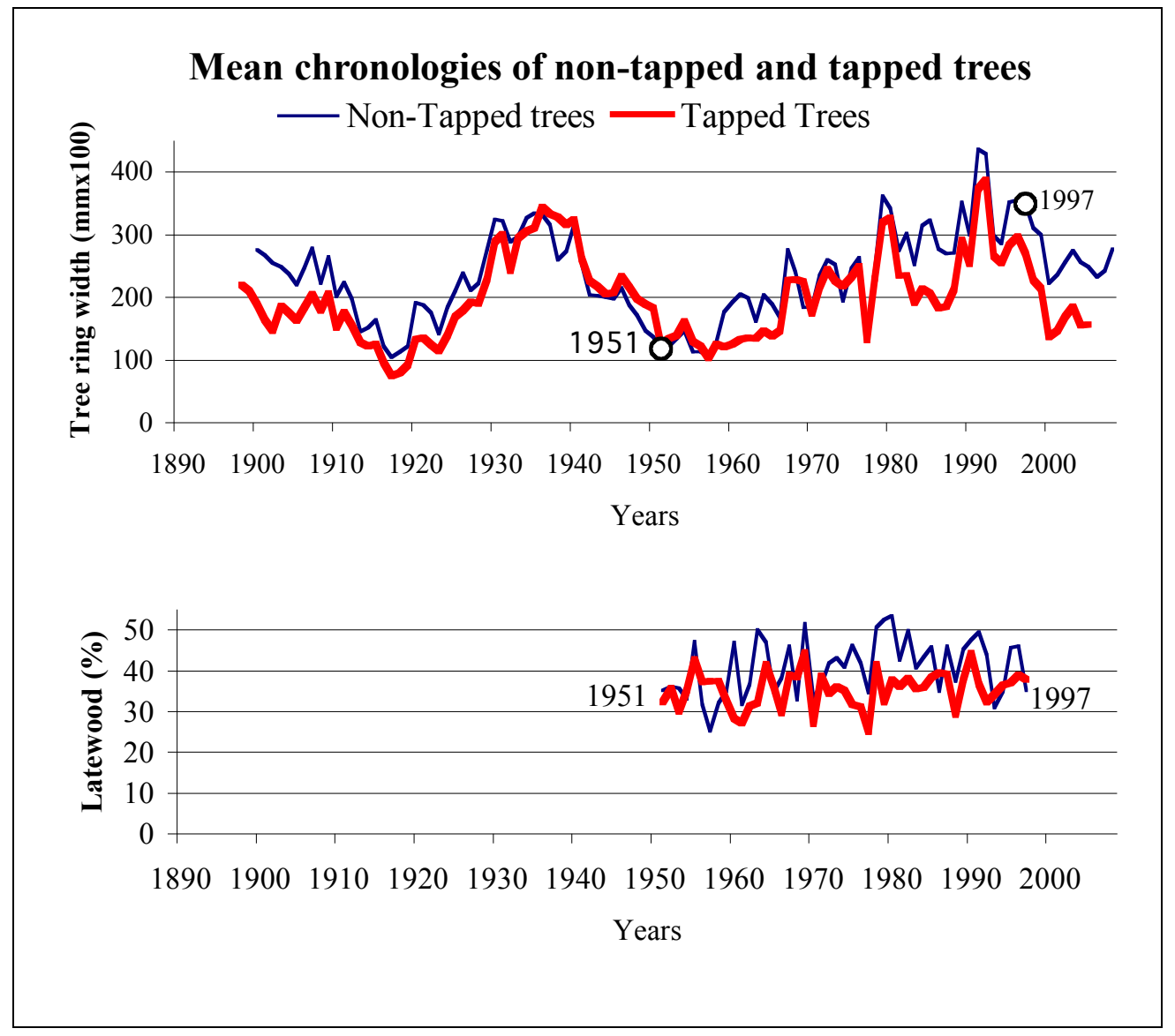

Fig. (3). Mean time chronologies of tree ring width and late wood proportion of non-tapped and tapped trees.

indicated by the number and frequency of opening faces, was very intense and can be characterized as fatal in many cases [1] in order to increase resin production. Tapping intensity decreased in the last approximately 30 years as a result of the reduced resin market price. Tapping intensity in the studied forest appears higher than the commonly used procedure where tapping ceases after the opening of 3 successive faces in a tree and for a maximum duration of 23 years [3]. This overuse is probably due to the greater productivity of the present stand which is characteristic of tapped forests in Northern Evia [3, 10]. Tapping results in a slight wood production decrease for the tapping period without this representing a serious problem due to the higher market value of the resin as compared to that of timber. Tapping by opening faces causes problems in wood structure in the lower part of the trunk (up to $2.5 \mathrm{~m}$ ).

To conclude, and based on the results of this research, it may be suggested that dendrochronology can substantially contribute to the investigation of Aleppo pine forests tapping history. This methodology can be applied to Aleppo pine forests by either sampling stumps of previously harvested trees or standing trees by taking cores using the standard increment borer. Specifically, sampling of a previously tapped standing tree may be performed at breast-height, at a part of the trunk without any obvious wounds and accordingly, in all tapping faces.

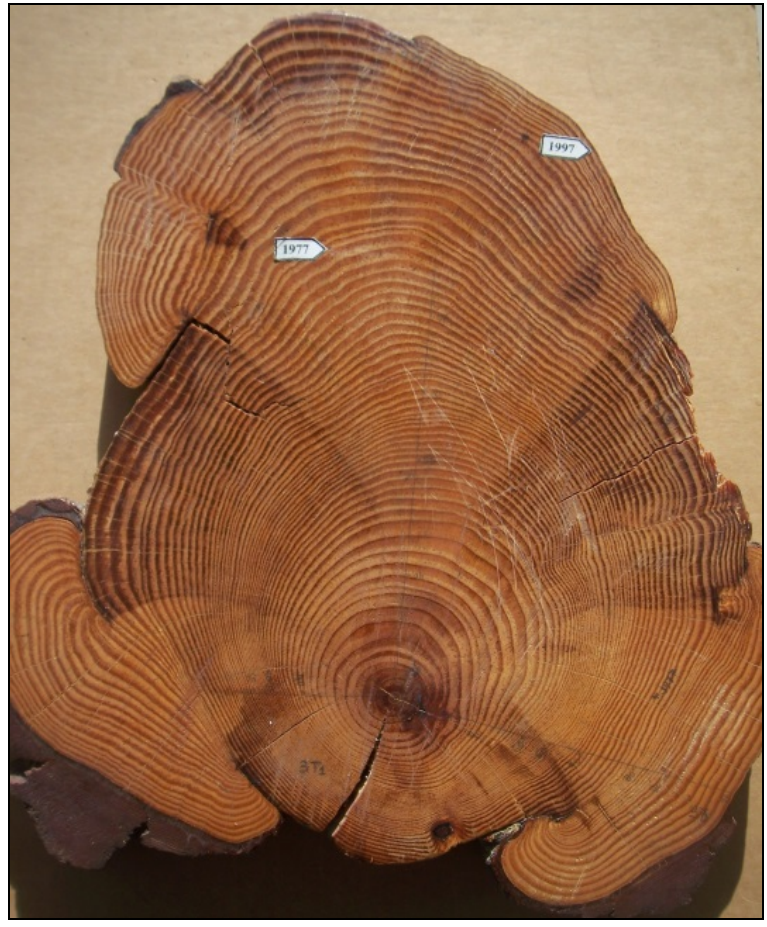

Fig. (4). Characteristic shape formation in the cross section of a tapped tree. 


\section{CONFLICT OF INTEREST}

The author confirms that this article content has no conflict of interest.

\section{ACKNOWLDGEMENTS}

The author is grateful to TEI Stereas Elladas and the Cost-STRESS-FP1106 Action.

\section{REFERENCES}

[1] Tsoumis G. Forest products harvesting. $2^{\text {nd }}$ ed. Aristotelian Univ. of Thessaloniki 1987 (in Greek).

[2] Schweingruber F. H. Tree rings and environment. Dendroecology. Birmensdorf: Haupt 1996.
[3] Papajannopoulos A. The present of resin tapping in Greece in front of the Agenda 2000 of the European Union. Geotechnical Scientific Issues 2000, 11(1): 123-32 (in Greek with English summary).

[4] Stokes MA, Smiley TL. An introduction to tree-ring dating. Chicago: The University of Chicago Press 1968.

[5] Fritts H.C. Tree-rings and climate. London: Academic Press 1976.

[6] Papadopoulos AM, Serre-Bachet F, Tessier L. Tree ring to climate relationships of Aleppo pine (Pinus halepensis Mill.) in Greece. Ecologia Mediterranea 2001; 27 (1): 89-98.

[7] Régant Instruments Inc. Windendro 2008a. For tree-ring analysis. Québec Canada 2007.

[8] Tsoumis G, Voulgaridis E, Passialis C. Application of paraquat to hard pine (Pinus brutia Ten.). Scientific Annals of the Dpt. of Forestry and Nat. Envir Aristotle Univ. of Thessaloniki 1990; Vol LC/2: 152-166. (in Greek with English summary).

[9] Tsoumis G. Crosses in trees. Proceedings of the $8^{\text {th }}$ Panhellenic Forestry Conference; 1998 Apr 6-8; Alexandroupolis, Greece. (in Greek with English summary).

[10] Spanos K, Gaitanis D, Spanos I. Resin production in natural pine stands in Northern Evia, Greece. Web Ecol 2010; 10: 38-43.

(C) A.M. Papadopoulos; Licensee Bentham Open

This is an open access article licensed under the terms of the Creative Commons Attribution Non-Commercial License (http://creativecommons.org/licenses/by$\mathrm{nc} / 3.0 /$ ) which permits unrestricted, non-commercial use, distribution and reproduction in any medium, provided the work is properly cited. 